\title{
Characterization of the Bioactivity and Mechanism of Bactenecin Derivatives Against Food-Pathogens
}

\author{
Changbao Sun', Liya Gu', Muhammad Altaf Hussain', Lijun Chen², Li Lin², \\ Haimei Wang ${ }^{1}$, Shiyue Pang ${ }^{1}$, Chenggang Jiang ${ }^{3}$, Zhanmei Jiang ${ }^{1 *}$ and Juncai Hou ${ }^{1 *}$ \\ ' Key Laboratory of Dairy Science, Ministry of Education, College of Food Science, Northeast Agricultural University, Harbin, \\ China, ${ }^{2}$ National Engineering Research Center of Dairy for Maternal and Child Health, Beijing Sanyuan Foods Co., Ltd., \\ Beijing, China, ${ }^{3}$ Harbin Veterinary Research Institute, Chinese Academy of Agricultural Sciences, Harbin, China
}

With the emergence of multidrug-resistant bacteria, antimicrobial peptides (AMPs) are regarded as potential alternatives to traditional antibiotics or chemicals. We designed and synthesized six derivatives of bactenecin $\left(\mathrm{L}_{2} \mathrm{C}_{3} \mathrm{~V}_{10} \mathrm{C}_{11}\right.$, RLCRIVIRVCR), including $\mathrm{R}_{2} \mathrm{~F}_{3} \mathrm{~W}_{10} \mathrm{~L}_{11} \quad$ (RRFRIVIRWLR), $\mathrm{R}_{2} \mathrm{~W}_{3} \mathrm{~W}_{10} \mathrm{R}_{11} \quad$ (RRWRIVIRWRR), $\mathrm{K}_{2} \mathrm{~W}_{3} \mathrm{~V}_{10} \mathrm{R}_{11}$ (RKWRIWIRVRR), $W_{2} R_{3} V_{10} R_{11}$ (RWRRIVIRVRR), $W_{2} K_{3} K_{10} R_{11}$ (RWKRIVVIRKRR), and $\mathrm{K}_{2} \mathrm{R}_{3} \mathrm{R}_{10} \mathrm{~K}_{11}$ (RKRRIVIRRKR), by amino acid substitution to increase the net charge and reduce hydrophobicity gradually. The bioactivity and mechanisms of action of the designed peptides were investigated. The results indicated that the antimicrobial activity of the designed peptides was higher than that of bactenecin. The hemolytic activity and cytotoxicity of the designed peptides were significantly lower than those of bactenecin. The designed peptides exhibited a wide range of antimicrobial activity against food-pathogens, particularly peptides $K_{2} W_{3} V_{10} R_{11}$ and $W_{2} R_{3} V_{10} R_{11}$; in addition, the activity was maintained under physiological salt and heat conditions. Mechanism studies indicated that AMPs interacted with negatively charged bacterial cell membranes, resulting in the destruction of cell membrane integrity by increasing membrane permeability and changing transmembrane potential, leading to cell death. The present study suggested that peptides $K_{2} W_{3} V_{10} R_{11}$ and $W_{2} R_{3} V_{10} R_{11}$ exhibited potential as alternatives to traditional antibiotics or chemicals for the treatment of food-pathogens. These findings lead to the development of a potential method for the design of novel AMPs.

Keywords: antibacterial peptides, bactenecin derivatives, food-pathogens, bioactivity, mechanism

\section{INTRODUCTION}

The spread of multidrug-resistant microorganisms (superbugs) has drawn increasing interest toward antimicrobial peptides (AMPs), which play important roles in the innate immune systems of many organisms, including vertebrates, invertebrates, plants, and microbes (Tao et al., 2017). AMPs act as the first line of innate defense showing a broad range of antimicrobial activity against food-pathogens (Steckbeck et al., 2014; De et al., 2018). Conventional chemicals and antibiotics mainly inhibit the biosynthesis of certain substances (such as cell wall, proteins, DNA, or RNA) in cells, leading to cell death. Owing to cationic and amphiphilic properties, most AMPs can interact 
with the negatively charged components such as the phosphate group in lipopolysaccharides (LPS) or teichoic acid on the outer membrane of Gram-negative and Gram-positive bacteria, respectively, disrupting cell membrane integrity, increasing cell membrane permeability, and changing transmembrane potential, leading to cell death (Shai, 2002; Hancock and Sahl, 2006; Tajbakhsh et al., 2018). Thus, this mechanism of action of antimicrobial peptides reduces the probability of bacterial resistance. AMPs are strong candidates to complement or substitute current antimicrobial agents.

Bactenecin, a 12-amino acid AMP found in bovine neutrophils (Romeo et al., 1988), is the smallest known cationic AMP with the sequence RLCRIVVIRVCR- $\mathrm{NH}_{2}$, which consist of 4 arginine residues, 2 cysteine residues, and 6 hydrophobic residues. The 2 cysteine residues form a disulfide bond that enabled the antimicrobial peptide molecules to form a folded structure (Wu and Hancock, 1999b). Evidence has shown that bactenecin exhibits extensive antimicrobial activity against bacteria, particularly Gram-negative bacteria (Hilpert et al., 2006), and strong cytotoxicity (Radermacher et al., 1993). However, compared with traditional antibiotics, many natural antimicrobial peptides are not suitable for industrial production because of stability, high extraction costs and biodisponibility problem. Thus, studies are being conducted on the design and synthesis of novel AMPs by using natural antimicrobial peptides as templates. Ding (2013) synthesized bactenecin linear derivatives (Bac8c), which are expected to enhance antibacterial activity and decrease cytotoxicity. The biological activity of antimicrobial peptides is linked to their physical and chemical properties, such as amphipathy, net charge, hydrophobicity, and structural characteristics (Hancock et al., 1995). Recent research has shown that a disulfide bond in bactenecin does not contribute significantly to its antimicrobial activity ( $\mathrm{Wu}$ and Hancock, 1999a,b). Thus, by amino acid substitution, we designed six linear derivatives of bactenecin acting as templates. The net charge of the designed peptides gradually increased with a decrease in hydrophobicity. The sequence of the derivatives $\left(\mathrm{R}_{2} \mathrm{~F}_{3} \mathrm{~W}_{10} \mathrm{~L}_{11}, \quad \mathrm{~W}_{2} \mathrm{R}_{3} \mathrm{~V}_{10} \mathrm{R}_{11}, \mathrm{~K}_{2} \mathrm{~W}_{3} \mathrm{~V}_{10} \mathrm{R}_{11}, \mathrm{R}_{2} \mathrm{~W}_{3} \mathrm{~W}_{10} \mathrm{R}_{11}\right.$, $\mathrm{W}_{2} \mathrm{~K}_{3} \mathrm{~K}_{10} \mathrm{R}_{11}$, and $\mathrm{K}_{2} \mathrm{R}_{3} \mathrm{R}_{10} \mathrm{~K}_{11}$ ) was RRFRIVVIRWLR$\mathrm{NH}_{2}$, RWRRIVVIRVRR-NH $\mathrm{N}_{2}, \quad$ RKWRIVVIRVRR-NH $\mathrm{N}_{2}$, RRWRIVVIRWRR-NH $\mathrm{N}_{2}$, RWKRIVVIRKRR-NH $\mathrm{N}_{2}$ and RKRRIVVIRRKR-NH $\mathrm{N}_{2}$, respectively. We compared the bioactivity of the seven synthesized peptides against foodpathogens and determined the antimicrobial mechanism of AMPs to develop bactenecin derivatives with higher antimicrobial activity, broader antibacterial spectrum, and lower cytotoxicity. This study aims to propose ideas and methods for the application of synthetic AMPs.

\section{MATERIALS AND METHODS}

\section{Materials}

All peptides were synthesized and purified by GL Biochem Co., Ltd., (Shanghai, China) by chemical solid-phase synthesis. The peptides were purified by reverse-phase high-performance liquid chromatography (RP-HPLC, LC3000, Beijing, China) with a purity of more than 95\%. The molecular weight of the peptides was measured by electrospray mass spectroscopy (Model Autoflex, Bruker Daltonics Inc., United States). The peptides were amidated at the C-terminus, dissolved in deionized water to $2.56 \mathrm{mM}$, and stored at $-20^{\circ} \mathrm{C}$.

The common food-pathogens (Salmonella typhimurium C7913, Escherichia coli ATCC25922, Salmonella Typhimurium C77-31, Salmonella enteric-subspenterica CMCC47020, Salmonella enteric- subspenterica CMCC50071, Cronobacter sakazakii ATCC29544, Salmonella Typhimurium ATCC14028, Listeria monocytogenes CMCC54004, Bacillus cereus CMCC6303, Staphylococcus aureus CMCC26074, Escherichia coli UB1005, Staphylococcus aureus ATCC25923) and human red blood cells (hRBCs) were purchased from the Harbin Veterinary Research Institute, Chinese Academy of Agricultural Sciences (Harbin, China). Human umbilical vein endothelial cells EA. hy 926 were purchased from Harbin Medical University. MuellerHinton broth (MHB) and Mueller- Hinton agar (MHA) were purchased from AOBOX Biotechnology Co., Ltd. (Beijing, China). Dulbecco's modified Eagle's medium (DMEM) and fetal bovine serum (FBS) were supplied by Gibco Life Technologies Co., Ltd. (New York, United States). All reagents (except for those specially noted) were of analytical grade and purchased from Kermel Chemical Reagent Co., Ltd. (Tianjin, China) and Sigma-Aldrich Co., Ltd. (Shanghai, China).

\section{Sequence Analysis of Peptides}

The primary structure of peptides was analyzed via the website http://www.expasy.org/tools/protparam.html. The hydrophobicity and hydrophobic moment of the peptides were analyzed via the website http://heliquest.ipmc.cnrs.fr/. Helical wheel projections were analyzed via the website http://lbqp.unb.br/NetWheels/.

\section{Circular Dichroism Spectra}

Conformational changes in peptides in different environments were characterized at $25^{\circ} \mathrm{C}$ with a J-810 spectropolarimeter (Jasco, Tokyo, Japan) using a quartz cell with $1.0 \mathrm{~mm}$ path length as described in a previous study (Zhu et al., 2015). The peptide solutions (final concentration of $150 \mu \mathrm{M}$ ) were dissolved in $10 \mathrm{mM}$ phosphate buffered saline (PBS, $\mathrm{pH} 7.4$ ), $50 \%$ trifluoroethanol (TFE), and $30 \mathrm{mM}$ sodium dodecyl sulfate (SDS), respectively. Spectra ranging from $190 \mathrm{~nm}$ to $250 \mathrm{~nm}$ were recorded at a scanning speed of $10 \mathrm{~nm} / \mathrm{min}$ and an average of 3 scans was collected for each peptide. The acquired CD spectra were then converted to the mean residue ellipticity by using the following equation: $\theta_{M}=\left(\theta_{\text {obs }} \times 1000\right) /(c \times 1 \times n)$, where $\theta_{M}$ is the mean residue ellipticity $\left(\mathrm{deg} \times \mathrm{cm}^{2} \times \mathrm{dmol}^{-1}\right), \theta_{\text {obs }}$ is the observed ellipticity corrected for the buffer at a given wavelength (mdeg), $\mathrm{c}$ is the peptide concentration $(\mathrm{mM}), \mathrm{l}$ is the path length $(\mathrm{mm})$, and $\mathrm{n}$ is the number of amino acids.

\section{Antimicrobial Activity}

The antimicrobial activity of each peptide against food-pathogens was characterized by the minimum inhibitory concentration (MIC) (Ma et al., 2013). A logarithmic growth-phase culture of bacteria $\left(1 \times 10^{6} \mathrm{CFU} / \mathrm{mL}\right)$ was mixed with peptide solutions 
(final concentration ranging from $0 \mu \mathrm{M}$ to $256 \mu \mathrm{M}$ ) in 96-well plates. After the 96 -well plates were incubated for $24 \mathrm{~h}$ at $37^{\circ} \mathrm{C}$, optical dispersion (OD) was measured using a microplate reader (Bio-Rad, $\imath$ Hercules, CA, United States) at $630 \mathrm{~nm}$. The MICs were determined as the lowest concentration of peptides at which no microbial growth was observed with the unaided eye visually. The broth with bacteria cells was used as the negative control, and un-inoculated broth was used as a positive control. The tests were performed in triplicate using three replicates for each experiment.

\section{Hemolytic Activity}

The hemolytic activity of peptides was determined by measuring the amount of hemoglobin released by human red blood cells (hRBCs) as described in a previous study (Luna-Ramírez et al., 2014). The hRBCs were washed and resuspended in $10 \mathrm{mM}$ PBS ( $\mathrm{pH} 7.4$ ) to attain a dilution of $\sim 2 \%$ heamatocrit. Then, $50 \mu \mathrm{L}$ of the hRBCs solution was incubated with $50 \mu \mathrm{L}$ of a serial dilution of peptides dissolved in PBS for $1 \mathrm{~h}$ at $37^{\circ} \mathrm{C}$. The mixtures were centrifuged, and the absorbance of the supernatant was measured using a microplate reader (BioRad, $\imath$ Hercules, CA, United States) at $570 \mathrm{~nm}$. The hRBCs treated with PBS (0\% hemolysis, $\left.\mathrm{A}_{0}\right)$ and $0.01 \%$ Triton $\mathrm{X}-$ $100\left(100 \%\right.$ hemolysis, $\left.A_{t}\right)$ acted as negative and positive controls, respectively. Melittin was used as a control peptide. The percentage of hemolysis was calculated using the following equation: Hemolysis $=\left[\left(\mathrm{A} \times \mathrm{A}_{0}\right) /\left(\mathrm{A}_{\mathrm{t}} \times \mathrm{A}_{0}\right)\right] \times 100 \%$.

\section{Cytotoxicity}

The cytotoxicity of the peptides was tested on the EA. hy 926 cell line by using the Cell Counting Kit-8 (CCK-8, Dojindo, Japan) as described in a previous study (Sánchez-Gómez et al., 2015). The EA. Hy 926 cells cultured in the logarithmic growth -phase was then diluted with PBS to a single cell suspension. A $100 \mu \mathrm{L}$ cell suspension $\left(2 \times 10^{5}\right.$ cells $)$ was added to 96 -well plates and cultured in an incubator with a $5 \% \mathrm{CO}_{2}$ atmosphere at $37^{\circ} \mathrm{C}$. The cell culture medium was removed, and the two-fold serial dilutions of peptides prepared using DMEM with 5\% FBS were added to the 96-well plates. After 24 h, $100 \mu \mathrm{L}$ DMEM with 10\% CCK- 8 was added to the 96-well plates and then cultured for $4 \mathrm{~h}$. The absorbance was measured at $492 \mathrm{~nm}$ by using a microplate reader. DMEM served as a positive control and cells mixed with DMEM without peptides as a negative control. Melittin was employed as a control peptide.

\section{Stability}

To evaluate the effect of different physiological conditions on the stability of peptides, we determined the salt stability, thermal stability, and enzymatic stability as described in a previous study (Dong, 2013; Sun et al., 2018). Escherichia coli ATCC25922 grown in the logarithmic phase $\left(1 \times 10^{6} \mathrm{CFU} / \mathrm{mL}\right)$ was exposed to each peptide at different salt concentrations $(150 \mathrm{mM} \mathrm{NaCl}$, $4.5 \mathrm{mM} \mathrm{KCl}, 6 \mu \mathrm{M} \mathrm{NH}{ }_{4} \mathrm{Cl}, 1 \mathrm{mM} \mathrm{MgCl}_{2}, 8 \mu \mathrm{M} \mathrm{ZnCl}_{2}, 2 \mathrm{mM}$ $\mathrm{CaCl}_{2}$, and $4 \mu \mathrm{M} \mathrm{FeCl}_{3}$ ). The peptides were treated for $1 \mathrm{~h}$ at $100^{\circ} \mathrm{C}$ to test for thermal stability. The peptides were treated with trypsin, pepsin, papain and protease $\mathrm{k}$ at a concentration of $1 \mathrm{mg} / \mathrm{mL}$ for $1 \mathrm{~h}$ at $37^{\circ} \mathrm{C}$ to test for enzyme stability. The control group consisted of untreated peptides. The subsequent assay was consistent with the MIC assay.

\section{Antibacterial Mechanism Study Outer Membrane Permeability}

The effect of peptides on the bacterial outer -membrane permeability was characterized by measuring the uptake of $N$-phenyl-1-naphthylamine (NPN) as described in a previous study (Zhu et al., 2014). In short, Escherichia coli UB1005 grown in the logarithmic phase was centrifuged at $2000 \mathrm{~g}$ and resuspended to an $\mathrm{OD}_{600} \mathrm{~nm}$ of 0.2 in $5 \mathrm{mM}$ of $4-(2-$ hydroxyethyl) piperazine-1-ethane sulfonic acid (HEPES, $\mathrm{pH}$ 7.2) with $5 \mathrm{mM}$ glucose. Subsequently, $2 \mathrm{~mL}$ of bacterial suspension was mixed with NPN (1 mM), and the background fluorescence $\left(\mathrm{F}_{0}\right)$ was recorded (excitation $\lambda=350 \mathrm{~nm}$, emission $\lambda=420 \mathrm{~nm}$ ) using an F-4500 fluorescence spectrophotometer (Hitachi, Tokyo, Japan). The peptides with final concentrations ranging from 1 to $16 \mu \mathrm{M}$ were then added to the bacterial suspension in a quartz cuvette. The fluorescence $\left(\mathrm{F}_{0 \mathrm{bs}}\right)$ was recorded over time until no further increase was observed. Polymyxin B $\left(\mathrm{F}_{100}\right)$ acted as a positive control for the test. The percent uptake of NPN was calculated using the following equation: $\mathrm{NPN}=\left(\mathrm{F}_{0 \mathrm{bs}}-\mathrm{F}_{0}\right) /\left(\mathrm{F}_{100}-\mathrm{F}_{0}\right) \times 100 \%$.

\section{Inner Membrane Permeability}

The effect of peptides on the bacterial cell inner membrane permeability was characterized by measuring the uptake of $O$-nitrophenyl- $\beta$-D-galactopyranoside (ONPG) as described in a previous study (Arias et al., 2014). Escherichia coli UB1005 grown in the logarithmic phase was centrifuged at $2000 \mathrm{~g}$ and resuspended to an $\mathrm{OD}_{600 \mathrm{~nm}}$ of 0.05 in PBS ( $5 \mathrm{mM}, \mathrm{pH} 7.4$ ) with $1.5 \mathrm{mM}$ ONPG. The peptides (at $1 \times \mathrm{MIC}$ ) were then mixed with bacterial suspension. The absorbance was recorded at $420 \mathrm{~nm}$ every $2 \min$ for $0 \sim 40 \mathrm{~min}$.

\section{Cytoplasmic Membrane Depolarization}

The effect of peptides on the cytoplasmic membrane depolarization of Escherichia coli UB1005 was determined using the membrane potential-sensitive fluorescent dye diSC $\mathrm{C}_{3}-5$ as described in a previous study (Shao et al., 2018). Escherichia coli UB1005 grown in the logarithmic phase was centrifuged at $2000 \mathrm{~g}$ and resuspended to an $\mathrm{OD}_{600} \mathrm{~nm}$ of 0.05 in $5 \mathrm{mM}$ HEPES (pH 7.2) with $20 \mathrm{mM}$ of glucose and $0.1 \mathrm{M} \mathrm{KCl}$. The bacterial suspensions were then mixed with $0.4 \mu \mathrm{M}$ diSC $_{3}-5$ and incubated for $1 \mathrm{~h}$ at $37^{\circ} \mathrm{C}$. Up to $2 \mathrm{~mL}$ of bacterial suspension with peptides (at $1 \times$ MIC) was placed in a quartz cuvette. Fluorescence intensity was monitored in the $0 \sim 300$ s range with an excitation wavelength of $622 \mathrm{~nm}$ and an emission wavelength of $670 \mathrm{~nm}$.

\section{Flow Cytometry}

The destruction of the bacterial cell membrane was measured using Escherichia coli ATCC25922 by flow cytometry (Mishra et al., 2013). Escherichia coli ATCC25922 grown in the logarithmic phase was centrifuged at $2000 \mathrm{~g}$ and resuspended to an $\mathrm{OD}_{600} \mathrm{~nm}$ of 0.2 in PBS ( $\mathrm{pH} 7.4$ ). The peptides at $1 \times$ MIC were added to the bacterial suspension and incubated in 
propidium iodide (PI) with a final concentration of $10 \mathrm{mg} / \mathrm{mL}$ for $30 \mathrm{~min}$ at $4^{\circ} \mathrm{C}$. The unbound dye was then washed with PBS. The data were recorded by fluorescence-activated cell sorting (Becton Dickinson, Franklin Lakes, NJ, United States).

\section{Electron Microscopic Characterization}

Damage to the integrity of bacterial cell membranes caused by peptides was characterized by scanning electron microscopy (SEM, Hitachi, Japan) and transmission electron microscopy (TEM, Hitachi, Tokyo, Japan) as described in a previous study (Tan et al., 2017). Escherichia coli ATCC25922 grown in the logarithmic -phase was centrifuged at $2000 \mathrm{~g}$ and resuspended to an $\mathrm{OD}_{600 \mathrm{~nm}}$ of 0.2 in PBS ( $\mathrm{pH} 7.4$ ). Peptides at $1 \times \mathrm{MIC}$ were added to the bacterial suspension and incubated for $2 \mathrm{~h}$ at $37^{\circ} \mathrm{C}$ in a shaker. The cells were washed three times with PBS and added into $1 \mathrm{~mL}$ of $3 \%$ glutaraldehyde, placed in a $4^{\circ} \mathrm{C}$ refrigerator for the night. The cells were then dehydrated with different concentrations of ethanol and tertiary butanol. In the preparation of the SEM sample, the cells were freezedried and coated with gold/palladium and then observed using the S-4800 SEM instrument. In the preparation of the TEM sample, the cells were incubated overnight in epoxy resin and acetone and then sectioned, stained, and observed using the H-7650 TEM instrument.

\section{Statistical Analysis}

All tests were conducted at least three times. The data were statistically analyzed using SPSS 20.0 via ANOVA and presented as the means \pm standard error.

\section{RESULTS}

\section{Sequence Analysis of Peptides}

The characteristics of the primary structural properties of native and designed peptides are listed in Table 1. A measured molecular weight value of each peptide was in very close agreement with its theoretical value, indicating the successful synthesis of the peptides. Table 1 reveals that all peptides exhibit cationic character, and the net charge is increased gradually in the following order: $\mathrm{L}_{2} \mathrm{C}_{3} \mathrm{~V}_{10} \mathrm{C}_{11}<\mathrm{R}_{2} \mathrm{~F}_{3} \mathrm{~W}_{10} \mathrm{~L}_{11}<\mathrm{R}_{2} \mathrm{~W}_{3} \mathrm{~W}_{10} \mathrm{R}_{11}$ $=\mathrm{K}_{2} \mathrm{~W}_{3} \mathrm{~V}_{10} \mathrm{R}_{11}=\mathrm{W}_{2} \mathrm{R}_{3} \mathrm{~V}_{10} \mathrm{R}_{11}<\mathrm{W}_{2} \mathrm{~K}_{3} \mathrm{~K}_{10} \mathrm{R}_{11}<\mathrm{K}_{2} \mathrm{R}_{3} \mathrm{R}_{10} \mathrm{~K}_{11}$. Conversely, the hydrophobicity of the peptides is decreased gradually with the increase in positive charge. The hydrophobicity of the peptides was determined theoretically and experimentally. The mean hydrophobicity $(\mathrm{H})$ was determined as the theoretical hydrophobicity of the peptides and calculated as the total hydrophobicity divided by the number of residues. The experimental hydrophobicity of the peptides was quantified using RP-HPLC retention time (Rt). The native peptide $\left(\mathrm{L}_{2} \mathrm{C}_{3} \mathrm{~V}_{10} \mathrm{C}_{11}\right)$ has the lowest net charge but the highest hydrophobicity and the peptides $K_{2} W_{3} V_{10} R_{11}$ and $W_{2} R_{3} V_{10} R_{11}$ have the same net charge and similar hydrophobicity. The relative hydrophobic moment ( $\mu \mathrm{Hrel}$ ), which reveals the amphiphilicity of the peptides, is positively correlated with amphiphilicity. The results showed that the $\mu$ Hrel value of the designed peptides was decreased gradually, ranging from 0.072 to 0.479 . Figure 1 presents an Edmundson helical wheel diagram of the amphiphilic properties of amino acid residues in each peptide. The wheel diagram and the relative hydrophobic moments revealed the designed peptides presented a better balance between the hydrophobic and hydrophilic phases.

\section{Circular Dichroism Spectra}

The secondary structures of peptides in different environments (10 mM PBS, 50\% TFE, and $30 \mathrm{mM}$ SDS) were determined by circular dichroism spectra, as shown in Figure 2. All CD spectra were analyzed using SELCON3 program (Sreerama et al., 2000), the results are summarized in Table 2. In PBS, all peptides appeared at a negative peak in the 195-202 nm range and a value near zero at $220 \mathrm{~nm}$, and the unordered content of theses peptides ranged from 51 to $66 \%$, indicating that peptides revealed the presence of discorded conformers in a mimic aqueous environment (Pandey et al., 2010). In SDS, all peptides displayed a positive peak in around $195-197 \mathrm{~nm}$ range and a typical negative peak at 217-218 nm, and showed a negative band at around $220 \mathrm{~nm}$, the $\alpha$-helical content of these peptides ranged from 38 to $49 \%$, the $\beta$-strand content of these peptides ranged from 20 to $29 \%$, indicating that these peptides revealed $\alpha$-helix and $\beta$-sheet structure in a mimic microbial membrane environment (Unger et al., 2001). In TFE, the peptides displayed a positive peak at around $191 \mathrm{~nm}$ and a negative dichroic bands at approximately 208 and $222 \mathrm{~nm}$, which is consistent with the predominant induction of $\alpha$-helix conformations in the mimic hydrophobic environment (Chou et al., 2016), the $\alpha$-helical content of these peptides ranged from 51 to $84 \%$. These data indicated that the $\alpha$-helical structural characteristic and the propensity to form an amphipathic $\alpha$-helix of the peptide in microbial membranemimetic environments may play an important role in killing bacterial cells.

\section{Antimicrobial Activity}

The antimicrobial effect of peptides on 12 typical food-pathogens is listed in Table 3. The geometric mean (GM) revealed the inhibitory effect of peptides against the food-pathogens. In Table 3, the GMs of the designed peptides (except $\mathrm{W}_{2} \mathrm{~K}_{3} \mathrm{~K}_{10} \mathrm{R}_{11}$, $\mathrm{K}_{2} \mathrm{R}_{3} \mathrm{R}_{10} \mathrm{~K}_{11}$ ) are markedly lower than that of the native peptide $\left(\mathrm{L}_{2} \mathrm{C}_{3} \mathrm{~V}_{10} \mathrm{C}_{11}\right)$, indicating that the antimicrobial activities of the peptides $\mathrm{R}_{2} \mathrm{~F}_{3} \mathrm{~W}_{10} \mathrm{~L}_{11}, \mathrm{R}_{2} \mathrm{~W}_{3} \mathrm{~W}_{10} \mathrm{R}_{11}, \mathrm{~K}_{2} \mathrm{~W}_{3} \mathrm{~V}_{10} \mathrm{R}_{11}$, and $W_{2} R_{3} V_{10} R_{11}$ were higher than that of the native peptide, $\mathrm{W}_{2} \mathrm{~K}_{3} \mathrm{~K}_{10} \mathrm{R}_{11}$ and $\mathrm{K}_{2} \mathrm{R}_{3} \mathrm{R}_{10} \mathrm{~K}_{11}$. The minimum hemolytic concentration (MHC) of the designed peptides were markedly higher than that of the native peptide $\left(\mathrm{L}_{2} \mathrm{C}_{3} \mathrm{~V}_{10} \mathrm{C}_{11}\right)$, indicating that the hemolytic activity of the designed peptides was lower than that of the native peptide. In addition to antimicrobial activity, the design of antimicrobial peptides should also consider the selectivity of peptides to mammalian cells. The selectivity index (SI), calculated as the ratio of MHC to GM, was used a comparison parameter for the safety and efficacy of peptides. The SI values of the designed peptides were evidently higher than that of the native peptide because of their higher MHC values. Specifically, the peptides $\mathrm{W}_{2} \mathrm{R}_{3} \mathrm{~V}_{10} \mathrm{R}_{11}, \mathrm{~K}_{2} \mathrm{~W}_{3} \mathrm{~V}_{10} \mathrm{R}_{11}$ had the highest SI values, indicating that they had considerably high levels of cell selectivity for pathogens. Table 3 shows that the 
TABLE 1 | Amino acid sequences and physicochemical properties of the peptides.

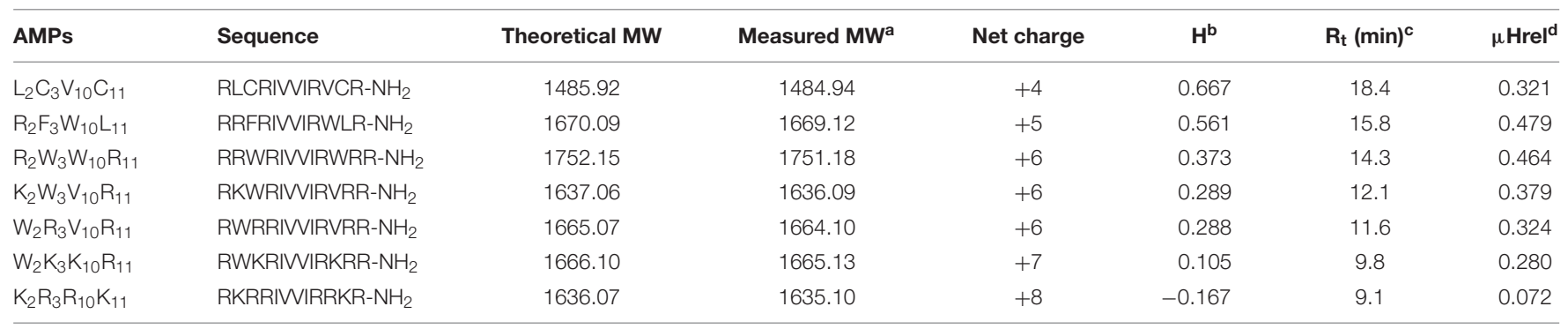

a Molecular weight (MW) was measured by mass spectroscopy (MS). ${ }^{b}$ The mean hydrophobicity $(H)$ is the total hydrophobicity (sum of all residue hydrophobicity indices) divided by the number of residues. ${ }^{c} R P$-HPLC retention time $\left(R_{t}\right)$ was measured using a $C_{18} R P$ column $\left(5 \mu \mathrm{m} ; 4.6 \times 250\right.$ nm; Vydac). ${ }^{d}$ The relative hydrophobic moment ( $\mu \mathrm{Hrel}$ ) of a peptide is its hydrophobic moment relative to that of a perfectly amphipathic peptide. This yields a better measure of the amphipathicity using different scales. A value of 0.5 indicates that the peptide has about $50 \%$ of the maximum possible amphipathicity.

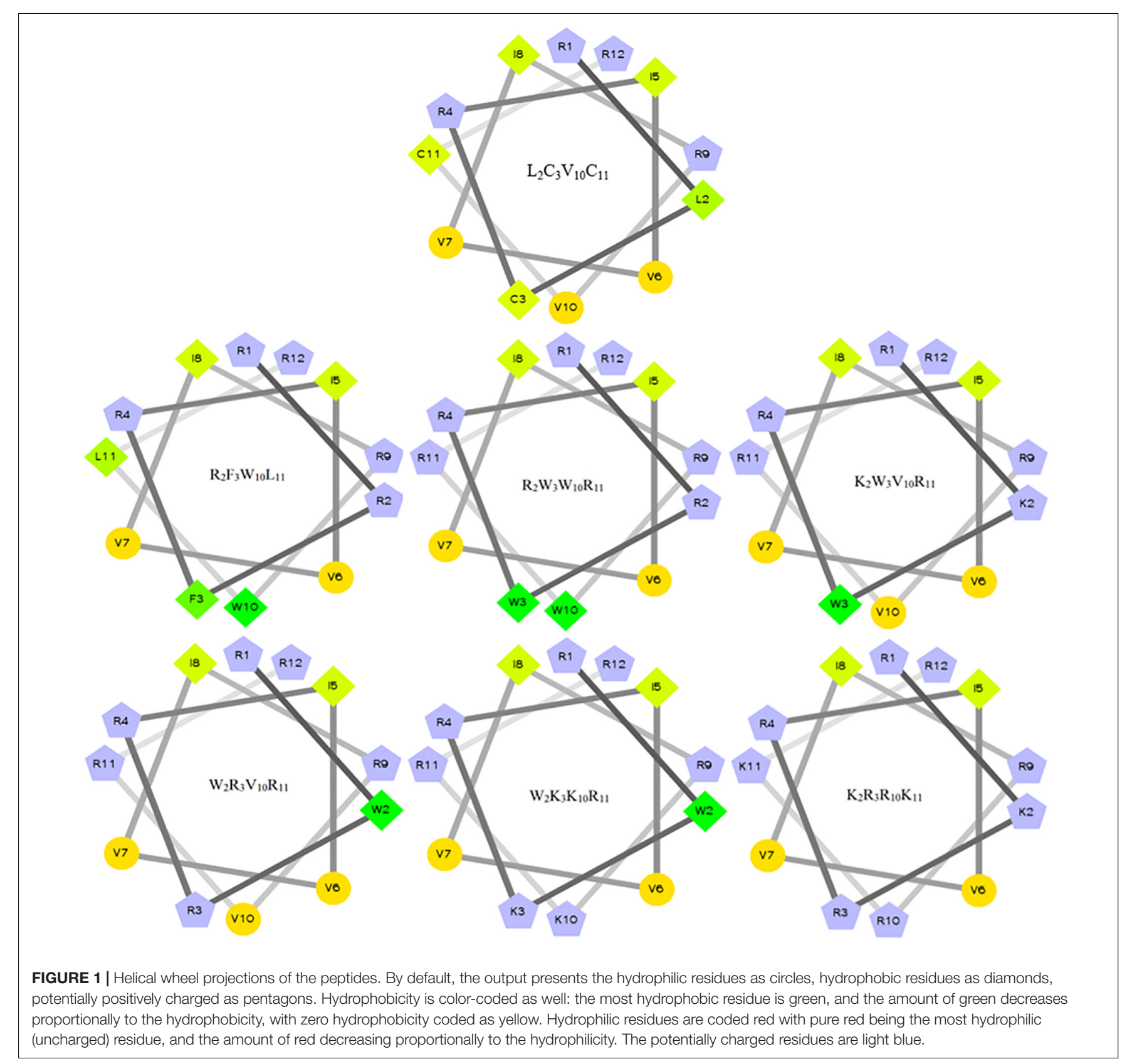



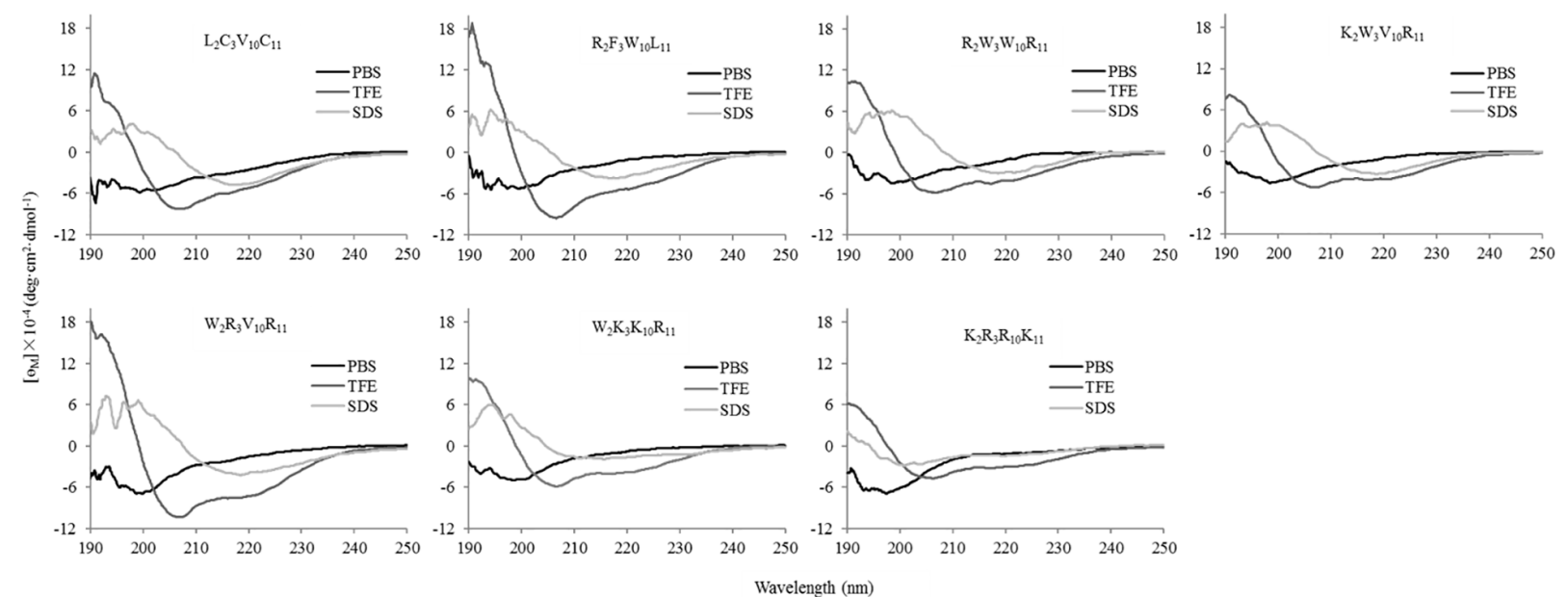

FIGURE 2 | The circular dichroism (CD) spectra of the peptides in different environments. The peptides were dissolved in $10 \mathrm{mM}$ phosphate buffered saline (PBS pH 7.4), 50\% trifluoroethanol (TFE), and $30 \mathrm{mM}$ sodium dodecyl sulfate (SDS), respectively. The mean residue ellipticity was plotted against wavelength. The values from three scans were averaged per sample, and the peptide concentrations were fixed at $150 \mu \mathrm{M}$.

TABLE 2 | Circular dichroism data of the peptides in various solutions.

\begin{tabular}{|c|c|c|c|c|c|c|c|c|c|c|c|c|}
\hline Peptides & \multicolumn{4}{|c|}{ PBS } & \multicolumn{4}{|c|}{ SDS } & \multicolumn{4}{|c|}{ TFE } \\
\hline $\mathrm{L}_{2} \mathrm{C}_{3} \mathrm{~V}_{10} \mathrm{C}_{11}$ & $2 \%$ & $10 \%$ & $25 \%$ & $65 \%$ & $38 \%$ & $24 \%$ & $21 \%$ & $24 \%$ & $51 \%$ & $21 \%$ & $17 \%$ & $18 \%$ \\
\hline $\mathrm{R}_{2} \mathrm{~F}_{3} \mathrm{~W}_{10} \mathrm{~L}_{11}$ & $5 \%$ & $17 \%$ & $20 \%$ & $61 \%$ & $44 \%$ & $23 \%$ & $13 \%$ & $22 \%$ & $55 \%$ & $10 \%$ & $14 \%$ & $21 \%$ \\
\hline $\mathrm{R}_{2} \mathrm{~W}_{3} \mathrm{~W}_{10} \mathrm{R}_{11}$ & $7 \%$ & $13 \%$ & $23 \%$ & $56 \%$ & $43 \%$ & $20 \%$ & $19 \%$ & $28 \%$ & $60 \%$ & $16 \%$ & $16 \%$ & $17 \%$ \\
\hline $\mathrm{K}_{2} \mathrm{~W}_{3} \mathrm{~V}_{10} \mathrm{R}_{11}$ & $11 \%$ & $14 \%$ & $15 \%$ & $66 \%$ & $49 \%$ & $23 \%$ & $15 \%$ & $20 \%$ & $84 \%$ & $10 \%$ & $11 \%$ & $9 \%$ \\
\hline $\mathrm{K}_{2} \mathrm{R}_{3} \mathrm{R}_{10} \mathrm{~K}_{11}$ & $7 \%$ & $21 \%$ & $21 \%$ & $58 \%$ & $40 \%$ & $29 \%$ & $16 \%$ & $21 \%$ & $60 \%$ & $10 \%$ & $20 \%$ & $13 \%$ \\
\hline
\end{tabular}

antibacterial activity and cell selectivity of the designed peptides was higher than that of the native peptide $\left(\mathrm{L}_{2} \mathrm{C}_{3} \mathrm{~V}_{10} \mathrm{C}_{11}\right)$, particularly for Gram-negative bacteria.

\section{Hemolytic Activity}

The hemolytic activity of the peptides was determined by measuring the amount of hemoglobin released by hRBCs (Figure 3). It is desirable that the MHC values of the peptides were as high as possible in comparison to the MIC. At peptide concentrations ranging from 0 to $256 \mu \mathrm{M}$, the hemolytic activity of native and designed peptides was significantly lower than that of melittin (positive control). The highest hemolytic activity of the native and designed peptides was only $23 \%$ at the concentration of $256 \mu \mathrm{M}$, whereas that of melittin was $100 \%$ at the concentration of $4 \mu \mathrm{M}$. The hemolytic activity of the designed peptides (except $\mathrm{K}_{2} \mathrm{R}_{3} \mathrm{R}_{10} \mathrm{~K}_{11}$ ) was similar to that of the native peptide when the peptide concentration was between 0 and $16 \mu \mathrm{M}$. Specifically, the hemolytic activity of the peptides $\mathrm{K}_{2} \mathrm{~W}_{3} \mathrm{~V}_{10} \mathrm{R}_{11}, \mathrm{~W}_{2} \mathrm{R}_{3} \mathrm{~V}_{10} \mathrm{~L}_{11}$, $\mathrm{W}_{2} \mathrm{~K}_{3} \mathrm{~K}_{10} \mathrm{R}_{11}$, and $\mathrm{K}_{2} \mathrm{R}_{3} \mathrm{R}_{10} \mathrm{~K}_{11}$ were lower than that of the native peptide when the peptide concentration exceeds $16 \mu \mathrm{M}$. Overall, the native peptide showed $5 \%$ hemolysis at $64 \mu \mathrm{M}$
(Table 3), the designed peptides caused 5\% hemolysis at the minimum concentration of $128 \mu \mathrm{M}$, indicating that the hemolytic activity of the designed peptides was lower than that of the native peptide.

\section{Cytotoxicity}

The cytotoxicity of the peptides against EA. hy 926 cells is shown in Figure 4. In general, the cytotoxicity of these peptides against EA. hy 926 cells was consistent with their hemolytic activities to hRBCs. The native and designed peptides exhibit significantly lower cytotoxicity than that of melittin (positive control) at peptides concentrations ranging from 1 to $128 \mu \mathrm{M}$. The viability of the EA. hy 926 cells decreased with an increase in peptide concentration. The cytotoxicity of melittin reached $100 \%$ at the concentration of $16 \mu \mathrm{M}$. When peptide concentration reached $128 \mu \mathrm{M}$, the EA. hy 926 cell viability of each peptide was as follows: $\mathrm{L}_{2} \mathrm{C}_{3} \mathrm{~V}_{10} \mathrm{C}_{11}$, $63 \% ; \mathrm{R}_{2} \mathrm{~F}_{3} \mathrm{~W}_{10} \mathrm{~L}_{11}, 71 \% ; \mathrm{R}_{2} \mathrm{~W}_{3} \mathrm{~W}_{10} \mathrm{R}_{11}, 77 \% ; \mathrm{K}_{2} \mathrm{~W}_{3} \mathrm{~V}_{10} \mathrm{R}_{11}, 80 \%$; $\mathrm{W}_{2} \mathrm{R}_{3} \mathrm{~V}_{10} \mathrm{R}_{11}, 80 \% ; \mathrm{W}_{2} \mathrm{~K}_{3} \mathrm{~K}_{10} \mathrm{R}_{11}, 83 \%$; and $\mathrm{K}_{2} \mathrm{R}_{3} \mathrm{R}_{10} \mathrm{~K}_{11}, 85 \%$. The designed peptides were less cytotoxic than the native peptide and showed much higher selectivity for EA. hy 926 cells, which is considered desirable. 
TABLE 3 | Antimicrobial activity of the peptides.

\begin{tabular}{|c|c|c|c|c|c|c|c|}
\hline & \multicolumn{7}{|c|}{$\mathrm{MIC}^{\mathrm{a}}(\mu \mathrm{M})$} \\
\hline & $L_{2} C_{3} V_{10} C_{11}$ & $R_{2} F_{3} W_{10} L_{11}$ & $\mathbf{R}_{2} \mathbf{W}_{3} \mathbf{W}_{10} \mathbf{R}_{11}$ & $K_{2} W_{3} V_{10} R_{11}$ & $W_{2} R_{3} V_{10} R_{11}$ & $W_{2} K_{3} K_{10} R_{11}$ & $\mathrm{~K}_{2} \mathrm{R}_{3} \mathrm{R}_{10} \mathrm{~K}_{11}$ \\
\hline \multicolumn{8}{|l|}{ Gram-negative bacteria } \\
\hline Escherichia coli ATCC25922 & 4 & 2 & 2 & 2 & 2 & 4 & 8 \\
\hline Escherichia coli UB1005 & 128 & 16 & 16 & 8 & 16 & 256 & 256 \\
\hline Salmonella typhimurium C77-31 & $>256$ & 64 & 64 & 32 & 32 & 256 & $>256$ \\
\hline Salmonella typhimurium ATCC14028 & 128 & 32 & 64 & 32 & 32 & 128 & 128 \\
\hline Salmonella pullorum C79-13 & $>256$ & 32 & 32 & 8 & 32 & 256 & 256 \\
\hline Salmonella enteric-subspenterica CMCC47020 & 128 & 64 & 256 & 64 & 128 & $>256$ & 256 \\
\hline Salmonella enteric-subspenterica CMCC50071 & 64 & 8 & 8 & 8 & 8 & 128 & $>256$ \\
\hline Cronobacter sakazakii ATCC29544 & 256 & 32 & 64 & 32 & 16 & 256 & $>256$ \\
\hline \multicolumn{8}{|l|}{ Gram-positive bacteria } \\
\hline Listeria monocytogenes CMCC54004 & 128 & 16 & 1 & 2 & 2 & 128 & 32 \\
\hline Bacillus cereus CMCC6303 & 64 & 32 & 64 & 16 & 64 & 128 & 128 \\
\hline Staphylococcus aureus CMCC26074 & $>256$ & 256 & 128 & 256 & 64 & $>256$ & $>256$ \\
\hline Staphylococcus aureus ATCC25923 & $>256$ & 256 & 128 & 128 & 256 & $>256$ & $>256$ \\
\hline$M H C^{b}(\mu \mathrm{M})$ & 64 & 128 & 128 & $>256$ & $>256$ & $>256$ & $>256$ \\
\hline $\mathrm{GM}^{\mathrm{c}}(\mu \mathrm{M})$ & 143.7 & 32.0 & 30.2 & 19.0 & 24.0 & 170.0 & 191.8 \\
\hline $\mathrm{SI}^{\mathrm{d}}$ & 0.5 & 4.0 & 4.2 & 26.9 & 21.5 & 3.0 & 2.7 \\
\hline
\end{tabular}

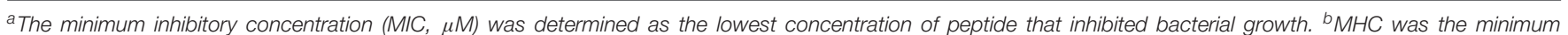

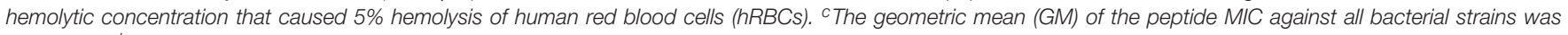
calculated. ${ }^{d}$ The selectivity index (SI) is the ratio of the MHC to the geometric mean of MIC. When MIC or MHC is over $256 \mu M$, a value of $512 \mu M$ is used to calculate.

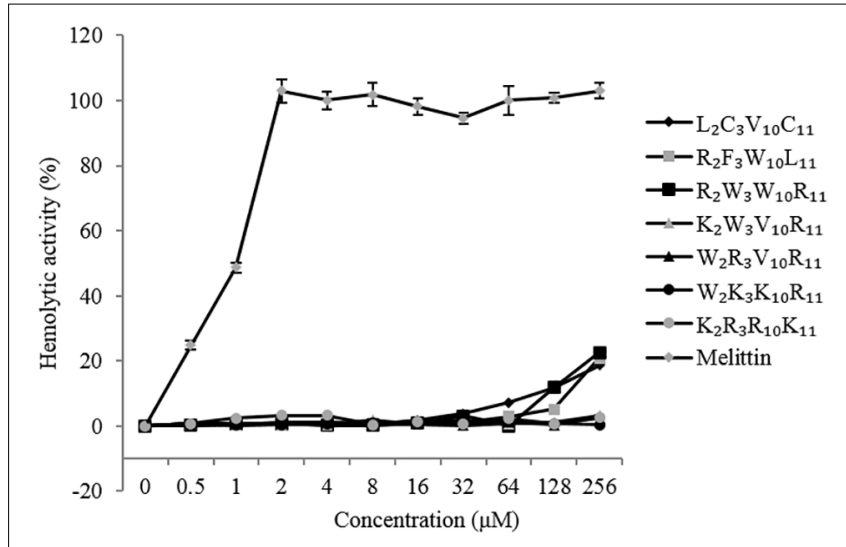

FIGURE 3 | Hemolytic activity of the peptides against human red blood cells (hRBCs).

\section{Stability}

To evaluate the stability of peptides under different salt, heat, and protease conditions, we determined the MICs of the peptides against Escherichia coli ATCC25922, because Gram-negative bacteria were sensitive to the designed peptides. Table 4 shows the change in the MICs of peptides under different conditions. All peptides exhibited increased MICs under $\mathrm{Na}^{+}$and heat conditions; in other salt conditions, the MICs of individual peptides increased. Notably, the change in MICs of all peptides remained considerably small, indicating that all peptides were relatively stable in different physiological concentrations of salt and heat. All peptides exhibited no sensitivity to papain. By

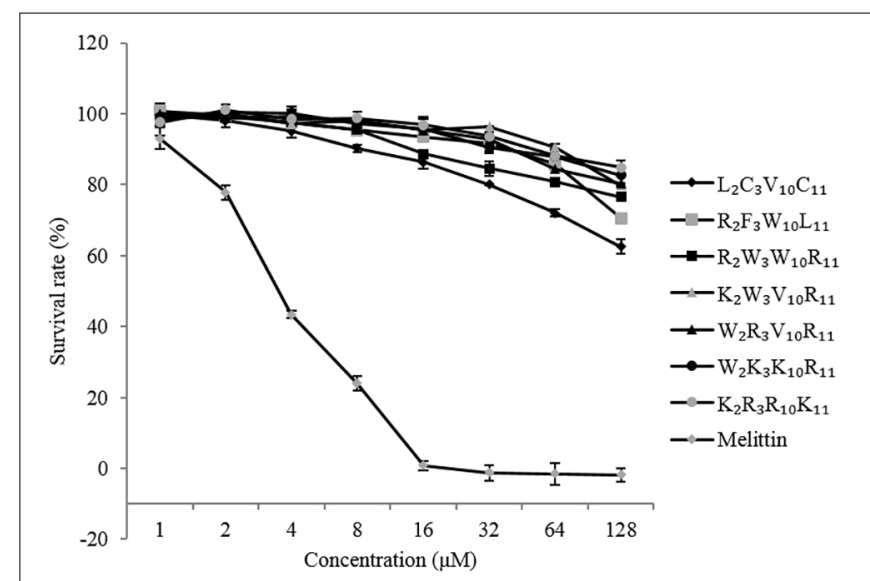

FIGURE 4 | Cytotoxicity of the peptides against EA. hy 926 cells.

contrast, all peptides showed sensitivity to trypsin, particularly designed peptides, which had almost no antimicrobial activity. The MIC of $\mathrm{K}_{2} \mathrm{~W}_{3} \mathrm{~V}_{10} \mathrm{R}_{11}$ varied markedly, reaching 128 and $256 \mu \mathrm{M}$ following treatment with pepsin and protease $\mathrm{k}$, respectively. The MICs of $\mathrm{R}_{2} \mathrm{~F}_{3} \mathrm{~W}_{10} \mathrm{~L}_{11}$ and $\mathrm{R}_{2} \mathrm{~W}_{3} \mathrm{~W}_{10} \mathrm{R}_{11}$ reached $128 \mu \mathrm{M}$ under proteinase $\mathrm{k}$ conditions.

\section{Antibacterial Mechanism Study}

With the biological activity of the aforementioned designed peptides considered, the peptides $\mathrm{R}_{2} \mathrm{~F}_{3} \mathrm{~W}_{10} \mathrm{~L}_{11}, \mathrm{R}_{2} \mathrm{~W}_{3} \mathrm{~W}_{10} \mathrm{R}_{11}$, $\mathrm{K}_{2} \mathrm{~W}_{3} \mathrm{~V}_{10} \mathrm{R}_{11}$, and $\mathrm{W}_{2} \mathrm{R}_{3} \mathrm{~V}_{10} \mathrm{R}_{11}$ were selected to explore the antibacterial mechanism of AMPs. 
TABLE 4 | MICa values of peptides in the presence of salts, heat and proteases.

\begin{tabular}{|c|c|c|c|c|c|c|c|c|c|c|c|}
\hline AMP & Control & $\mathrm{NaCl}^{\mathrm{b}}$ & $\mathrm{KCl}^{\mathrm{b}}$ & $\mathrm{MgCl}_{2}{ }^{\mathrm{b}}$ & $\mathrm{CaCl}_{2}{ }^{\mathrm{b}}$ & $\mathrm{NH}_{4} \mathrm{Cl}^{\mathrm{b}}$ & Heat $^{c}$ & Pepsin ${ }^{d}$ & Trypsin ${ }^{d}$ & Papain $^{d}$ & Proteinase $\mathbf{k}^{\mathrm{d}}$ \\
\hline $\mathrm{L}_{2} \mathrm{C}_{3} \mathrm{~V}_{10} \mathrm{C}_{11}$ & 4 & 16 & 4 & 4 & 8 & 4 & 8 & 16 & 64 & 16 & 32 \\
\hline $\mathrm{R}_{2} \mathrm{~F}_{3} \mathrm{~W}_{10} \mathrm{~L}_{11}$ & 2 & 16 & 8 & 2 & 8 & 4 & 32 & 16 & $>256$ & 8 & 128 \\
\hline $\mathrm{R}_{2} \mathrm{~W}_{3} \mathrm{~W}_{10} \mathrm{R}_{11}$ & 2 & 4 & 2 & 2 & 2 & 2 & 8 & 32 & $>256$ & 4 & 128 \\
\hline $\mathrm{K}_{2} \mathrm{~W}_{3} \mathrm{~V}_{10} \mathrm{R}_{11}$ & 2 & 8 & 2 & 4 & 8 & 2 & 8 & 128 & $>256$ & 2 & 256 \\
\hline$W_{2} R_{3} V_{10} R_{11}$ & 2 & 4 & 2 & 4 & 8 & 2 & 4 & 32 & $>256$ & 2 & 8 \\
\hline $\mathrm{W}_{2} \mathrm{~K}_{3} \mathrm{~K}_{10} \mathrm{R}_{11}$ & 4 & 8 & 4 & 4 & 4 & 4 & 16 & 16 & $>256$ & 4 & 8 \\
\hline $\mathrm{K}_{2} \mathrm{R}_{3} \mathrm{R}_{10} \mathrm{~K}_{11}$ & 8 & 32 & 8 & 8 & 16 & 8 & 16 & 32 & $>256$ & 8 & 8 \\
\hline
\end{tabular}

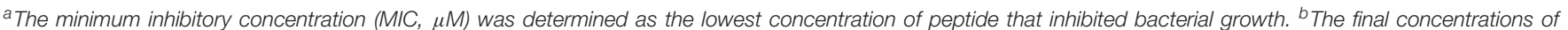

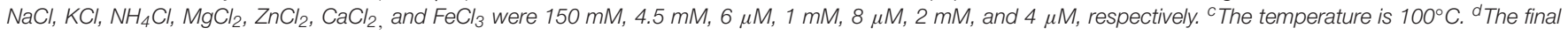
concentrations of trypsin, pepsin, papain and protease $\mathrm{k}$ were $1 \mathrm{mg} / \mathrm{mL}$.

\section{Outer Membrane Permeability}

The hydrophobic fluorophore NPN is normally excluded by the outer membrane, but it is taken up and exhibits increased fluorescence intensity upon permeabilization of the outer membrane. Figure 5 shows the effect of peptides on the outer membrane permeability of Escherichia coli UB1005 by measuring NPN uptake. The four designed peptides increased the outer membrane permeability of Escherichia coli UB1005 in a dosedependent manner at concentrations from 1 to $16 \mu \mathrm{M}$. Under the same concentration, the NPN uptake caused by the peptide $\mathrm{K}_{2} \mathrm{~W}_{3} \mathrm{~V}_{10} \mathrm{R}_{11}$ was higher than those of the other three peptides, indicating that the outer membrane permeability attributed to the peptide $\mathrm{K}_{2} \mathrm{~W}_{3} \mathrm{~V}_{10} \mathrm{R}_{11}$ was the largest, and the destruction of the outer membrane was the largest, which was related to the antibacterial activity of the peptide $\mathrm{K}_{2} \mathrm{~W}_{3} \mathrm{~V}_{10} \mathrm{R}_{11}$ to Escherichia coli UB1005.

\section{Inner Membrane Permeability}

The peptides induced permeabilization of the inner membrane, ONPG entered the cytoplasm and was degraded by $\beta$-galactosidase into o-nitrophenol, which produced absorbance at $420 \mathrm{~nm}$. We investigated the inner membrane permeabilization induced by the peptides by measuring the ONPG uptake (Figure 6). The peptides induced an increase in inner membrane permeability in a time-dependent manner at $1 \times$ MIC. The inner membrane permeability of the peptide $\mathrm{R}_{2} \mathrm{~F}_{3} \mathrm{~W}_{10} \mathrm{~L}_{11}$ was similar to that of the peptide $\mathrm{R}_{2} \mathrm{~W}_{3} \mathrm{~W}_{10} \mathrm{R}_{11}$ and markedly higher than those of the other two peptides. The peptides, arranged in descending order with respect to membrane permeability, were as follows: $\mathrm{R}_{2} \mathrm{~F}_{3} \mathrm{~W}_{10} \mathrm{~L}_{11}>\mathrm{R}_{2} \mathrm{~W}_{3} \mathrm{~W}_{10} \mathrm{R}_{11}>\mathrm{K}_{2} \mathrm{~W}_{3} \mathrm{~V}_{10} \mathrm{R}_{11}>\mathrm{W}_{2} \mathrm{R}_{3} \mathrm{~V}_{10} \mathrm{R}_{11}$.

\section{Cytoplasmic Membrane Depolarization}

The depolarization effect of peptides at $1 \times$ MIC on the Escherichia coli UB1005 cytoplasmic membrane was evaluated by measuring the fluorescence intensity of diSC $_{3}-5$. Upon the permeabilization and disruption of the outer and inner membrane, the electrical potential of the cytoplasmic membrane will change. The cationic dye is concentrated in the cytoplasmic membrane under the influence of the internally negative membrane potential. In Figure 7 , the peptides cause a rapid

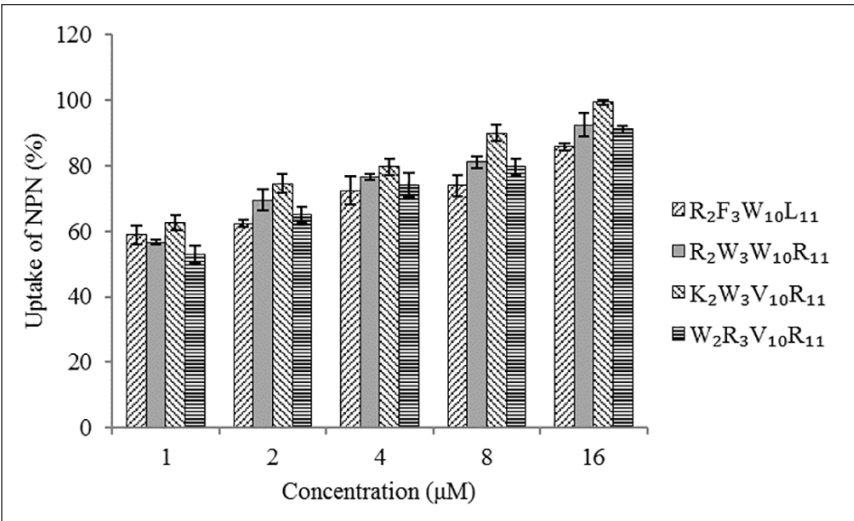

FIGURE 5 | Outer membrane permeability of the peptides. The uptake of NPN of Escherichia coli UB1005 in the presence of peptides at $1 \times$ MIC was determined using the fluorescent dye NPN assay at an excitation wavelength of $350 \mathrm{~nm}$ and an emission wavelength of $420 \mathrm{~nm}$.

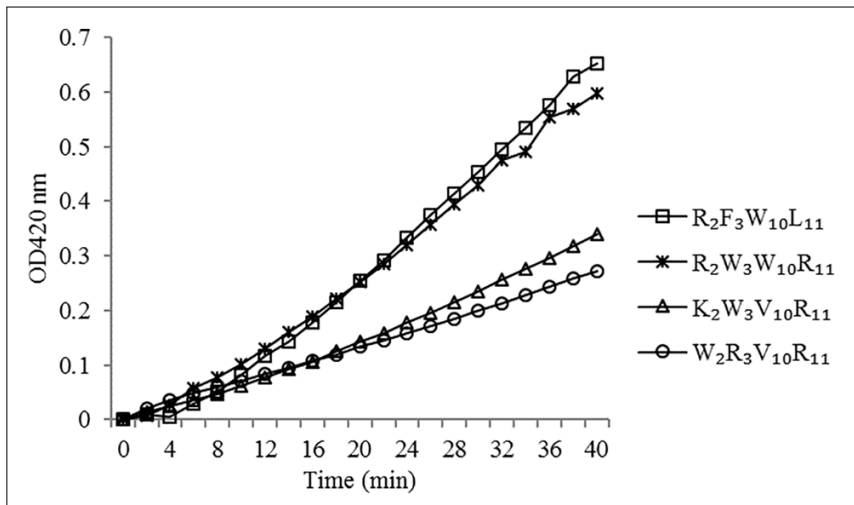

FIGURE 6 | Inner membrane permeability of the peptides. The uptake of ONPG of Escherichia coli UB1005 treated with peptides at $1 \times \mathrm{MIC}$ was determined at an excitation wavelength of $420 \mathrm{~nm}$.

increase in fluorescence intensity, reflecting cytoplasmic membrane depolarization. The cytoplasmic membrane of the peptide $\mathrm{R}_{2} \mathrm{~W}_{3} \mathrm{~W}_{10} \mathrm{R}_{11}$ was depolarized faster and stronger, compared with other peptides over $300 \mathrm{~s}$. The peptides, arranged in descending order with respect to cytoplasmic membrane depolarization, were as follows: 


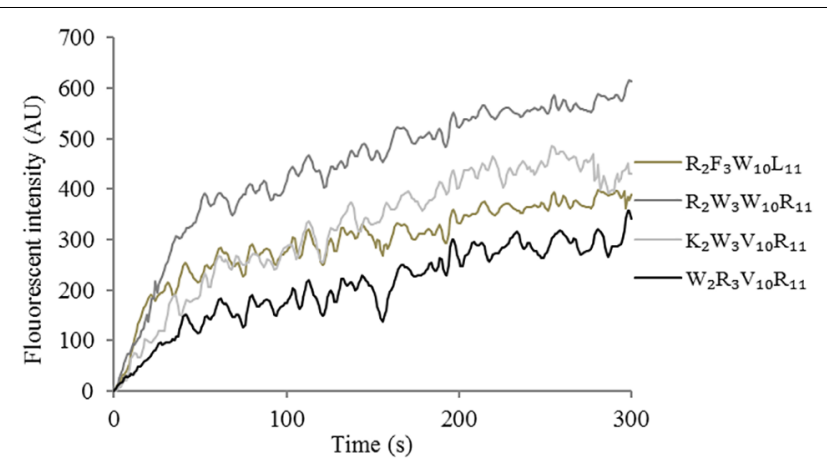

FIGURE 7 | Cytoplasmic membrane depolarization of Escherichia coli UB1005 treated with peptides at $1 \times$ MIC was assessed by measuring the release of the membrane potential-sensitive fluorescent dye diSC $\mathrm{S}_{3}-5$ at an excitation wavelength of $622 \mathrm{~nm}$ and an emission wavelength of $670 \mathrm{~nm}$ from 0 s to 300 s.

$\mathrm{R}_{2} \mathrm{~W}_{3} \mathrm{~W}_{10} \mathrm{R}_{11}>\mathrm{K}_{2} \mathrm{~W}_{3} \mathrm{~V}_{10} \mathrm{R}_{11}>\mathrm{R}_{2} \mathrm{~F}_{3} \mathrm{~W}_{10} \mathrm{~L}_{11}>\mathrm{W}_{2} \mathrm{R}_{3} \mathrm{~V}_{10} \mathrm{R}_{11}$. The increasing fluorescence intensity indicated that cytoplasmic membrane depolarization exhibited time dependence.

\section{Flow Cytometry}

To further evaluated the broken effect of AMPs on bacteria Escherichia coli ATCC25922 cell membranes, we detected a PI fluorescent signal by flow cytometry (Figure 8). PI fluorescently stained the nucleic acids of cells when cells suffered disruption of cytoplasmic membrane integrity. The results showed that only $0.1 \%$ of the fluorescent signals were observed in the control (no peptide), indicating that most cell membranes were intact. The PI fluorescent signals were $70,79,85$, and $83 \%$ at the concentration of $1 \times \mathrm{MIC}$, suggesting that most bacterial cell membranes were destroyed, the peptide $\mathrm{K}_{2} \mathrm{~W}_{3} \mathrm{~V}_{10} \mathrm{R}_{11}$ and $\mathrm{W}_{2} \mathrm{R}_{3} \mathrm{~V}_{10} \mathrm{R}_{11}$ were more destructive.

\section{Electron Microscopic Characterization}

Morphological changes in Escherichia coli ATCC25922 cells treated with peptides were observed by SEM and TEM (Figure 9). The cells treated with peptides at the concentration of $1 \times$ MIC showed evident membrane damage compared with the control (no peptide). The membrane surface was complete and smooth without obvious holes. The surface of the bacterial cell membrane surface became rough and wrinkled, atrophied, and fractured. The cells produced significant leakage and fracture. Intracellular changes of bacteria in Escherichia coli ATCC25922 cells were observed by TEM. The control (no peptide) exhibited an intact and smooth surface, distinct cell wall, and evenly distributed cell contents. The cells treated with AMPs at the concentration of $1 \times$ MIC showed apparent intracellular alteration; the distribution of the intracellular contents was no longer uniform and separated from the membrane. The cell membrane was destroyed, revealing holes, and the intracellular content was leaked, resulting in cells death.

\section{DISCUSSION}

Owing to the increasing resistance of pathogens to antibiotics, AMPs emerged as a potential alternative to antibiotics for AMPs kill bacteria by destroying the integrity of cell membranes, greatly reducing the likelihood of bacterial resistance. The objective of the present study was to develop bactenecin derivatives with higher antimicrobial activity, broader antibacterial spectrum, and lower cytotoxicity. The biological activity of AMPs is linked to their physicochemical properties, such as net charge, hydrophobicity, amphipathy and so on. In this study, arginine and lysine were introduced in the designed peptides to increase the electrostatic interaction with the negatively charged surface of bacterial membranes (Ma et al., 2011), tryptophan and phenylalanine were introduced in the designed peptides to ensure a more efficient interaction with the interface of lipid bilayers (Kyoungsoo et al., 2002).

Most AMPs possess a positive charge, whereas bacteria have a negative charge on their cell membranes. Thus, AMPs can play an antibacterial role by combining with bacterial cell membranes via electrostatic attraction. The introduction of a positive charge into the antimicrobial peptide can lead to an increase in its antimicrobial activity, which may be due to the improved stability of the molecular structure (e.g., $\alpha$-helix) of the peptide. No positive correlation exists between the number of positive charges and antibacterial activity. In the current study, the peptides arranged in ascending order with respect to net charge, as follows: $\mathrm{L}_{2} \mathrm{C}_{3} \mathrm{~V}_{10} \mathrm{C}_{11}(+4)<\mathrm{R}_{2} \mathrm{~F}_{3} \mathrm{~W}_{10} \mathrm{~L}_{11}$ $(+5)<\mathrm{R}_{2} \mathrm{~W}_{3} \mathrm{~W}_{10} \mathrm{R}_{11}(+6)=\mathrm{K}_{2} \mathrm{~W}_{3} \mathrm{~V}_{10} \mathrm{R}_{11}(+6)=\mathrm{W}_{2} \mathrm{R}_{3} \mathrm{~V}_{10} \mathrm{R}_{11}$ $(+6)<\mathrm{W}_{2} \mathrm{~K}_{3} \mathrm{~K}_{10} \mathrm{R}_{11}(+7)<\mathrm{K}_{2} \mathrm{R}_{3} \mathrm{R}_{10} \mathrm{~K}_{11}(+8)$. The antibacterial activity of peptides initially increased and then decreased as the net charge of the peptides increased (Table 3). On the one hand, the positive charge keep AMPs adherent to the surface of cell membranes, reducing its ability to penetrate the membranes; on the other hand, this occurrence may increase electrostatic repulsion among peptide molecules; when the electrostatic repulsion is greater than the electrostatic attraction between AMPs and cell membranes, aggregation of antibacterial peptide molecules on cell membranes is prevented (Matsuzaki, 1999). The two cysteine residues form a disulfide bond to make the native peptide a loop molecule, which reduces the tendency to form amphiphilic helical structures, leading to lower antimicrobial activity. The antibacterial activities of the peptides $\mathrm{K}_{2} \mathrm{~W}_{3} \mathrm{~V}_{10} \mathrm{R}_{11}$ and $W_{2} R_{3} V_{10} R_{11}$ were significantly higher, compared with the other peptides. At a net charge of +6 , the peptides $K_{2} W_{3} V_{10} R_{11}$ and $\mathrm{W}_{2} \mathrm{R}_{3} \mathrm{~V}_{10} \mathrm{R}_{11}$ exhibited the highest (and similar) antibacterial activity. The reason could be that the hydrophobic valine residue in position 10 is more likely to form a stable $\alpha$-helical structure due to its relatively small side chain; $\alpha$-helical structure plays an important role in antimicrobial activity of antimicrobial peptides. Furthermore, the consecutive same positively charged amino acids may result in steric hindrance and charge repulsion, causing the disruption of helix formation, leading to a significant reduction in antimicrobial activity (Zhu et al., 2015).

Hydrophobicity is another important factor that defines the antimicrobial potency, and the hydrophobicity of these substituted amino acid residues decreased in the order 

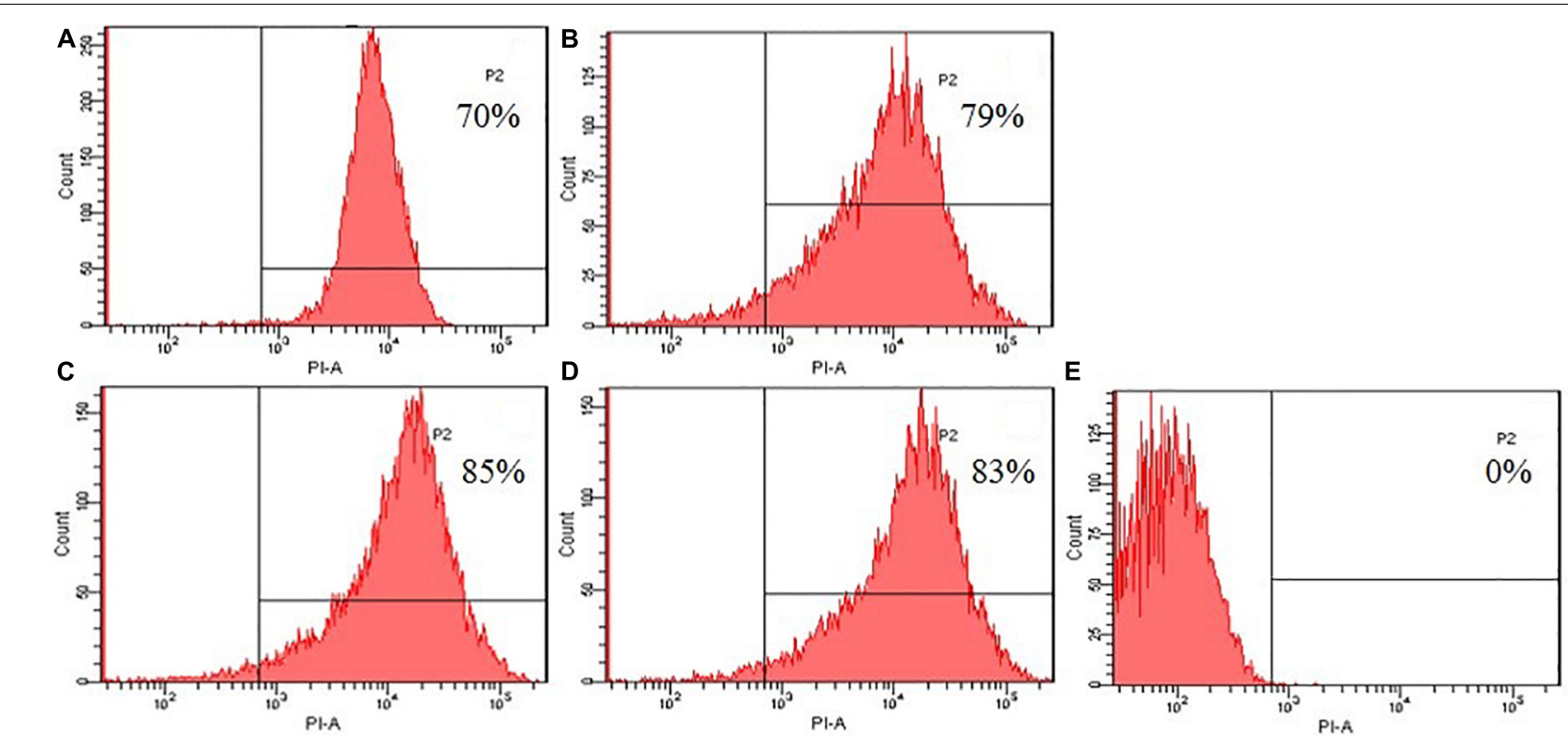

FIGURE 8 | Destruction of cytomembrane integrity treated by peptides. The uptake of PI of Escherichia coli ATCC25922 treated with peptides at $1 \times$ MIC was determined at $4^{\circ} \mathrm{C}$ for 30 min. (A) $R_{2} F_{3} W_{10} L_{11}$; (B) $R_{2} W_{3} W_{10} R_{11} ;$ (C) $K_{2} W_{3} V_{10} R_{11} ;$ (D) $W_{2} R_{3} V_{10} R_{11}$; (E) Control.

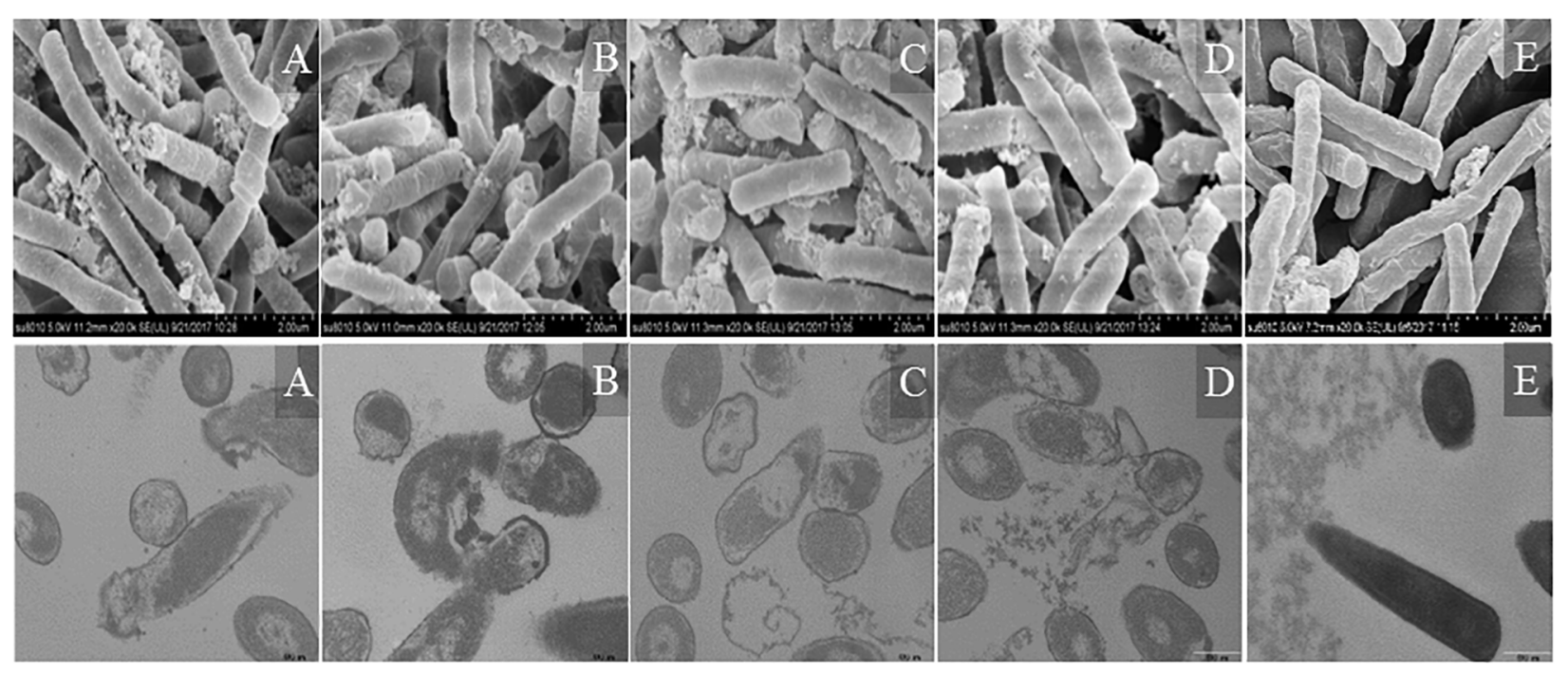

FIGURE 9 | SEM and TEM micrographs of Escherichia coli ATCC25922 cells treated with peptides at $1 \times M_{I C}$ for 1 h. (A) $R_{2} F_{3} W_{10} L_{11} ;(\mathbf{B}) R_{2} W_{3} W_{10} R_{11}$; (C) $\mathrm{K}_{2} \mathrm{~W}_{3} \mathrm{~V}_{10} \mathrm{R}_{11} ;$ (D) $\mathrm{W}_{2} \mathrm{R}_{3} \mathrm{~V}_{10} \mathrm{R}_{11} ;$ (E) Control.

Val $>\operatorname{Trp}>$ Lys $>$ Arg, consistent with the order of antimicrobial activity of these peptides. The hydrophobic groups of amino acids allow AMP molecules to form a polysome by the hydrophobic action in the solution and played an improved role in the cell membrane. On the one hand, low hydrophobicity could weaken the ability of AMP molecules to bind to cell membranes; while high hydrophobicity could cause the AMP molecules to aggregate. Extreme cationicity and hydrophobicity have been found to hamper selective electrostatic interactions and favor interactions with zwitterionic phospholipids, concomitantly and inadvertently resulting in an increase in cytotoxicity and loss of cell selectivity (Zhang et al., 2010; Huang Y. B. et al., 2011). The hemolytic activity and cytotoxicity of AMPs limit their application. The higher the hydrophobicity, the greater the hemolytic activity and cytotoxicity of AMPs (Zhang et al., 2010). Compared with melittin, the native and designed peptides showed lower hemolytic activity and cytotoxicity (Figures 3,4 ). Overall, the designed peptides had lower hemolytic activity and cytotoxicity than the native peptide. The hemolytic activity and cytotoxicity 
of the peptides bactenecin, $\mathrm{R}_{2} \mathrm{~F}_{3} \mathrm{~W}_{10} \mathrm{~L}_{11}$, and $\mathrm{R}_{2} \mathrm{~W}_{3} \mathrm{~W}_{10} \mathrm{R}_{11}$ were higher than those of the other peptides. The reason could be that these peptides exhibited relatively higher hydrophobicity and relative hydrophobic moment (amphiphilicity) because they contain more hydrophobic amino acids residues. Previous studies have shown that hemolytic activity is positively correlated with the side chain hydrophobicity of the substituting amino acid residue, peptide hydrophobicity, amphipathicity (Hawrani et al., 2008). Furthermore, the disruption of the hydrophobic face by the introduction of a charged residue was reported to significantly reduce hemolytic activity and cytotoxicity without deteriorating antimicrobial activity.

Amphipathicity also appear to have influence on the antimicrobial activity of AMPs. Amphipathic residue arrangement is important for the activity of $\alpha$-helical AMPs because the polar region allows the molecules to assemble on the membrane through electrostatic interaction with the negatively charged head groups of phospholipids, and then the non-polar region would lead to the formation of transient pores or channels through hydrophobic interactions, causing increased permeability and loss of barrier function of target cells (Sato and Feix, 2006). If the peptides display helix formation in the membrane environment, they would have greater affinity for the anionic membrane and have enhanced incorporation into lipid membranes, further increasing the antimicrobial activity of AMPs (Ahmad et al., 2013). Amphiphilicity affects the conformation of AMPs in different environments. Circular dichroism spectroscopy can provide useful information about the conformations and structural changes of the peptides in different environments. Most AMPs adopt the $\alpha$-helical and/or $\beta$-sheet structures (Wang et al., 2013; Wiradharma et al., 2013), which are beneficial for the interaction between antimicrobial peptides and cell membranes (Henzler Wildman et al., 2003; Dong et al., 2012), and this phenomenon is particularly evident from CD spectral studies. The amphipathic AMPs undergo important conformational changes from random coils in aqueous solution to helical structures induced by anisotropic environments. Our results indicated that the designed peptides appear to present higher helical content than the native peptide. In $10 \mathrm{mM}$ PBS, the native and designed peptides showed a disordered structure in a mimic aqueous environment; in $50 \% \mathrm{TFE}$, these peptides exhibited an $\alpha$-helical structure in a mimic microbial membrane environment; in $30 \mathrm{mM}$ SDS, these peptides adopted a mixed $\alpha$-helix and $\beta$-sheet structure in the SDS-micellular membrane mimicking environment. Given the structural data from the CD studies, it is clear that the amphipathicity structure significantly increases the propensity for $\alpha$-helix formation in the bacterial membrane-mimicking environments, which is correlated with the antimicrobial activity of AMPs. The presence of the basic residue in the peptide sequence could also contribute to a stabilizing effect to the helical structure by increasing the helical macrodipole and providing an extra hydrogen bonding between lateral chains especially arginine. Cation $-\pi$ interactions occur between basic residues (lysine and arginine) and aromatic residues (tryptophan and phenylalanine) and are important for peptide self-association within membranes and facilitate deeper insertion into membranes by shielding cationic side chains (Gallivan and Dougherty, 1999).

Studies on numerous natural peptides have shown that some cations $\left(\mathrm{Na}^{+}\right.$and $\left.\mathrm{Mg}^{2+}\right)$ may affect the activity of peptides relying on the interruption of the electrostatic attraction between the positively charged peptides and the negatively charged membranes and the competition for membrane binding between the peptides and cations (Wu et al., 2008; Mcdonnell et al., 2012). Electrostatic interaction between cationic peptides and cell membranes is necessary for peptides to kill bacteria (Saardover et al., 2012). The higher the ionic strength, the lower the electrostatic adsorption between the cationic AMPs and the lipid bilayers of the bacterial anionic cell membrane, causing a decrease in antibacterial activity (Huang J. et al., 2011). However, in this study, cations caused a 2-4-fold change in MIC values, indicating that the designed peptides still maintained a relatively desirable active state. The designed peptides showed salt-resistance, possibly owing to their high net charge, which can overcome cationic masking by anions in salts and promote peptide interaction with the cell membranes (Sugiarto and $\mathrm{Yu}, 2007$ ). The designed peptides maintained high antibacterial activity after treatment at $100^{\circ} \mathrm{C}$ for $1 \mathrm{~h}$, suggesting that the designed peptides showed good thermal stability. This finding is consistent with the results of a recent study by $\mathrm{Ma}$ et al. (2012). The reason may be that the peptides present a disordered structure in mimicking the aqueous environment and forms $\alpha$-helical structure or $\beta$-sheet structure in mimicking the membrane environment. The antibacterial activity of antimicrobial peptides treated with enzymes decreased to varying degrees. The antimicrobial peptides treated by the enzyme showed antibacterial activity reduced to varying degrees, potentially resulting from the different amounts of arginine. The stability of peptides to enzymes was slightly low. In the presence of salt and heat, the peptides generally showed high antibacterial activity, exhibiting potential application for further development of antibacterial agents.

The action mechanism of AMPs depends on their damage to cell membranes integrity via barrel-stave or toroidal-pore mechanisms, or induce 'micellization' by carpet mechanisms (Brogden, 2005). The bacterial cell outer membranes consist of negatively charged teichoic acid, or LPS, hydroxy-phospholipids such as phosphatidylserine, cardiolipin and phosphatidylglycerol, which promote interaction with cationic peptides (Teixeira et al., 2012; Mai et al., 2017). The cationic antimicrobial peptides are electrostatically attracted by the negatively charged bacterial surface layers and get itself embedded into the hydrophobic regions of the lipid membranes, leading to destruction of the organism by formation of transient pores or channels, destabilization of membrane equilibrium, or penetration into the cell, causing increased membrane permeability, membrane depolarization, cell cytoplasmic membrane lysis, and cytoplasmic leakage; ultimately, this process leads to cell death (Ong et al., 2014). In this study, Gram-negative bacteria were more sensitive to the designed peptides and more clearly observed, Escherichia coli ATCC25922 cells were used as an indicator strain. This is because the cell wall of Gram-positive bacteria is relatively thick, containing a large amount of peptide-glycan and teichoic 
acid, while the cell wall of Gram-negative bacteria is relatively thin, containing a large number of LPS, phospholipids and a small amount of peptide-glycan, which leads to the loose outer membrane structure of Gram-negative bacteria, making it easier for antimicrobial peptides to embed into the cell membrane. The results of this study indicated that the designed peptides could rapidly damage the bacterial cell outer membrane. Moreover, the designed peptides at $1 \times$ MIC were able to permeabilize the inner membrane. As a result of cell membrane rupture, cytoplasmic membrane potentially increased, leading to cytoplasmic leakage and ultimately, cell death. The results of SEM and TEM confirmed the strong membrane rupture ability of the designed peptides.

\section{CONCLUSION}

We designed and synthesized cationic AMPs based on the native peptide (bactenecin, $\mathrm{L}_{2} \mathrm{C}_{3} \mathrm{~V}_{10} \mathrm{C}_{11}$ ) and then evaluated their bioactivity. These peptides exhibited a disordered structure in an aqueous solution but folded into an $\alpha$-helical structure and/or $\beta$-sheet structure in a membrane environment. The designed peptides exhibited stronger antimicrobial activity, lower level of hemolysis, and cytotoxicity than those of the native peptide, especially $\mathrm{K}_{2} \mathrm{~W}_{3} \mathrm{~V}_{10} \mathrm{R}_{11}$ and $\mathrm{W}_{2} \mathrm{R}_{3} \mathrm{~V}_{10} \mathrm{R}_{11}$. At MIC, the peptides permeabilized the bacterial cell outer and inner membrane, and depolarized the cytoplasmic membrane, disrupting the integrity

\section{REFERENCES}

Ahmad, A., Margitta, D., and Alfred, B. (2013). The helical propensity of KLA amphipathic peptides enhances their binding to gel-state lipid membranes. Biophys. Chem. 180-181, 10-21. doi: 10.1016/j.bpc.2013. 05.003

Arias, M., Mcdonald, L. J., Haney, E. F., Nazmi, K., Bolscher, J. G., and Vogel, H. J. (2014). Bovine and human lactoferricin peptides: chimeras and new cyclic analogs. Biometals 27, 935-948. doi: 10.1007/s10534-014-9753-4

Brogden, K. A. (2005). Antimicrobial peptides: pore formers or metabolic inhibitors in bacteria? Nat. Rev. Microbiol. 3, 238-250. doi: 10.1038/ nrmicro1098

Chou, S., Shao, C., Wang, J., Shan, A., Xu, L., Dong, N., et al. (2016). Short, multiple-stranded $\beta$-hairpin peptides have antimicrobial potency with high selectivity and salt resistance. Acta Biomater. 30, 78-93. doi: 10.1016/j.actbio. 2015.11.002

De, B. A., Riool, M., Cordfunke, R. A., Malanovic, N., De, B. L., Koning, R. I., et al. (2018). The antimicrobial peptide SAAP-148 combats drug-resistant bacteria and biofilms. Sci. Trans. Med. 10:eaan4044. doi: 10.1126/scitranslmed.aan 4044

Ding, Y. (2013). Antimicrobial Derivatives Activity of Bactenecin and its Against Cariogenic Bacteria. Shaanxi: Fourth Military Medical University.

Dong, N. (2013). Studies on Molecular Design, Biological Activities, and Mechanisms of $\beta$-Sheet Antimicrobial Peptides. Harbin: Northeast Agricultural University.

Dong, N., Ma, Q., Shan, A., Lv, Y., Hu, W., Gu, Y., et al. (2012). Strand length-dependent antimicrobial activity and membrane-active mechanism of arginine- and valine-rich $\beta$-hairpin-like antimicrobial peptides. Antimicrob. Agents Chemother. 56:2994. doi: 10.1128/AAC.06327-11

Gallivan, J. P., and Dougherty, D. A. (1999). Cation-pi interactions in structural biology. Proc. Natl. Acad. Sci. U.S.A. 96, 9459-9464. doi: 10.1073/pnas.96.17. 9459

Hancock, R. E., Falla, T., and Brown, M. (1995). Cationic bactericidal peptides. $A d v$. Microb. Physiol. 37, 135-175. doi: 10.1016/s0065-2911(08)60145-9 of the membrane. This disruption caused cytoplasm leakage, leading to cell death. All these results indicated that the designed peptides exerted an antibacterial effect against food-pathogens. The findings of this study also provide a rationalization for the design of antibacterial peptides, which is important for the future development of antimicrobial agents.

\section{DATA AVAILABILITY STATEMENT}

All datasets generated for this study are included in the article/supplementary material.

\section{AUTHOR CONTRIBUTIONS}

CS and HW designed the study. LC, LL, CJ, and LG provided advice on experimental design and data analysis. LG and SP collected and assembled the data. CS wrote the manuscript. CS and $\mathrm{MH}$ revised the manuscript. $\mathrm{JH}$ and $\mathrm{ZJ}$ supervised the study. All authors reviewed and commented on the manuscript.

\section{FUNDING}

We gratefully acknowledge the financial support of the National Key Research and Development Program of China (Grant Number 2016YFD0400605).

Hancock, R. E., and Sahl, H. G. (2006). Antimicrobial and host-defense peptides as new anti-infective therapeutic strategies. Nat. Biotechnol. 24, 1551-1557. doi: $10.1038 /$ nbt1267

Hawrani, A., Howe, R., Walsh, T., and Dempsey, C. (2008). Origin of low mammalian cell toxicity in a class of highly active antimicrobial amphipathic helical peptides. J. Biol. Chem. 283, 18636-18645. doi: 10.1074/jbc.M709154200

Henzler Wildman, K. A., Lee, D. K., and Ramamoorthy, A. (2003). Mechanism of lipid bilayer disruption by the human antimicrobial peptide. LL-37. Biochemistry 42, 6545-6558. doi: 10.1021/bi0273563

Hilpert, K., Elliott, M. R., Volkmer-Engert, R., Henklein, P., Donini, O., Zhou, Q., et al. (2006). Sequence requirements and an optimization strategy for short antimicrobial peptides. Chem. Biol. 13, 1101-1107. doi: 10.1016/j.chembiol. 2006.08.014

Huang, J., Hao, D., Chen, Y., Xu, Y., Tan, J., Huang, Y., et al. (2011). Inhibitory effects and mechanisms of physiological conditions on the activity of enantiomeric forms of an $\alpha$-helical antibacterial peptide against bacteria. Peptides 32, 1488-1495. doi: 10.1016/j.peptides.2011.05.023

Huang, Y. B., Wang, X. F., Wang, H. Y., Liu, Y., and Chen, Y. (2011). Studies on mechanism of action of anticancer peptides by modulation of hydrophobicity within a defined structural framework. Mol. Cancer Ther. 10:416. doi: 10.1158/ 1535-7163.MCT-10-0811

Kyoungsoo, P., Donghoon, O., Yub, S. S., Kyung-Soo, H., and Yangmee, K. (2002). Structural studies of porcine myeloid antibacterial peptide PMAP-23 and its analogues in DPC micelles by NMR spectroscopy. Biochem. Biophys. Res. Commun. 290, 204-212. doi: 10.1006/bbrc.2001.6173

Luna-Ramírez, K., Sani, M. A., Silva-Sanchez, J., Jiménez-Vargas, J. M., ReynaFlores, F., Winkel, K. D., et al. (2014). Membrane interactions and biological activity of antimicrobial peptides from australian scorpion. Biochim. Biophys. Acta 1838, 2140-2148. doi: 10.1016/j.bbamem.2013.10.022

Ma, Q. Q., Dong, N., Shan, A. S., Lv, Y. F., Li, Y. Z., Chen, Z. H., et al. (2012). Biochemical property and membrane-peptide interactions of de novo antimicrobial peptides designed by helix-forming units. Amino Acids 43, 2527-2536. doi: 10.1007/s00726-012-1334-7 
Ma, Q. Q., Lv, Y. F., Gu, Y., Dong, N., Li, D. S., and Shan, A. S. (2013). Rational design of cationic antimicrobial peptides by the tandem of leucine-rich repeat. Amino Acids 44, 1215-1224. doi: 10.1007/s00726-012-1457-X

Ma, Q. Q., Shan, A. S., Dong, N., Gu, Y., Sun, W. Y., Hu, W. N., et al. (2011). Cell selectivity and interaction with model membranes of Val/Arg-rich peptides. J. Pept. Sci. 17, 520-526. doi: 10.1002/psc.1360

Mai, S., Mauger, M. T., Niu, L. N., Barnes, J. B., Kao, S., Bergeron, B. E., et al. (2017). Potential applications of antimicrobial peptides and their mimics in combating caries and pulpal infections. Acta Biomater. 49:S1742706116306225. doi: 10.1016/j.actbio.2016.11.026

Matsuzaki, K. (1999). Why and how are peptide-lipid interactions utilized for self-defense? magainins and tachyplesins as archetypes. Biochim. Biophys. Acta Biomembr. 1462, 1-10. doi: 10.1016/s0005-2736(99)00197-2

Mcdonnell, M. J., Rivas, L., Burgess, C. M., Fanning, S., and Duffy, G. (2012). Inhibition of verocytotoxigenic Escherichia coli by antimicrobial peptides caseicin $\mathrm{A}$ and $\mathrm{B}$ and the factors affecting their antimicrobial activities. Int. J. Food Microbiol. 153, 260-268. doi: 10.1016/j.ijfoodmicro.2011.10.001

Mishra, B., Leishangthem, G. D., Gill, K., Singh, A. K., Das, S., Singh, K., et al. (2013). A novel antimicrobial peptide derived from modified N-terminal domain of bovine lactoferrin: design, synthesis, activity against multidrugresistant bacteria and Candida. BBA Biomembr. 1828, 677-686. doi: 10.1016/ j.bbamem.2012.09.021

Ong, Z. Y., Wiradharma, N., and Yang, Y. Y. (2014). Strategies employed in the design and optimization of synthetic antimicrobial peptide amphiphiles with enhanced therapeutic potentials. Adv. Drug Deliv. Rev 78, 28-45. doi: 10.1016/ j.addr.2014.10.013

Pandey, B. K., Ahmad, A., Asthana, N., Azmi, S., Srivastava, R. M., Srivastava, S., et al. (2010). Cell-selective lysis by novel analogues of melittin against human red blood cells and Escherichia coli. Biochemistry 49, 7920-7929. doi: 10.1021/ bi100729m

Radermacher, S. W., Schoop, V. M., and Schluesener, H. J. (1993). Bactenecin, a leukocytic antimicrobial peptide, is cytotoxic to neuronal and glial cells. J. Neurosci. Res. 36, 657-662. doi: 10.1002/jnr.490360606

Romeo, D., Skerlavaj, B., Bolognesi, M., and Gennaro, R. (1988). Structure and bactericidal activity of an antibiotic dodecapeptide purified from bovine neutrophils. J. Biol. Chem. 263, 9573-9575.

Saardover, R., Bitler, A., Nezer, R., Shmuelgalia, L., Firon, A., Shimoni, E., et al. (2012). D-alanylation of lipoteichoic acids confers resistance to cationic peptides in group B streptococcus by increasing the cell wall density. Plos Pathog. 8:e1002891. doi: 10.1371/journal.ppat.1002891

Sánchez-Gómez, S., Ferrer-Espada, R., Stewart, P. S., Pitts, B., Lohner, K., and Tejada, G. M. D. (2015). Antimicrobial activity of synthetic cationic peptides and lipopeptides derived from human lactoferricin against Pseudomonas aeruginosa planktonic cultures and biofilms. BMC Microbiol. 15:137. doi: 10 . 1186/s12866-015-0473-x

Sato, H., and Feix, J. B. (2006). Peptide-membrane interactions and mechanisms of membrane destruction by amphipathic $\alpha$-helical antimicrobial peptides. Biochim. Biophys. Acta 1758, 1245-1256. doi: 10.1016/j.bbamem.2006.02.021

Shai, Y. (2002). Mode of action of membrane active antimicrobial peptides. Biopolymers 66, 236-248. doi: 10.1002/bip.10260

Shao, C., Tian, H., Wang, T., Wang, Z., Chou, S., Shan, A., et al. (2018). Central $\beta$ turn increases the cell selectivity of imperfectly amphipathic $\alpha$-helical peptides. Acta Biomater. 69, 243-255. doi: 10.1016/j.actbio.2018.01.009

Sreerama, N., Venyaminov, S. Y., and Woody, R. W. (2000). Estimation of protein secondary structure from circular dichroism spectra: inclusion of denatured proteins with native proteins in the analysis. Anal. Biochem. 287, 243-251. doi: 10.1006/abio.2000.4879

Steckbeck, J. D., Deslouches, B., and Montelaro, R. C. (2014). Antimicrobial peptides: new drugs for bad bugs? Expert Opin. Biol. Ther. 14, 11-14. doi: $10.1517 / 14712598.2013 .844227$

Sugiarto, H., and Yu, P. L. (2007). Effects of cations on antimicrobial activity of ostricacins-1 and 2 on E. coli O157:H7 and S. aureus 1056MRSA. Curr. Microbiol. 55:36. doi: 10.1007/s00284-006-0554-z
Sun, C., Li, Y., Cao, S., Wang, H., Jiang, C., Pang, S., et al. (2018). Antibacterial activity and mechanism of action of bovine lactoferricin derivatives with symmetrical amino acid sequences. Intern. J. Mol. Sci. 19:2951. doi: 10.3390/ ijms 19102951

Tajbakhsh, M., Karimi, A., Tohidpour, A., Abbasi, N., Fallah, F., and Akhavan, M. M. (2018). The antimicrobial potential of a new derivative of cathelicidin from Bungarus fasciatus against methicillin-resistant Staphylococcus aureus. J. Microbiol. 56, 128-137. doi: 10.1007/s12275-018-7444-5

Tan, T., Wu, D., Li, W., Zheng, X., Li, W., and Shan, A. (2017). High specific selectivity and membrane-active mechanism of synthetic cationic hybrid antimicrobial peptides based on the peptide FV7. Intern. J. Mol. Sci. 18:339. doi: 10.3390/ijms18020339

Tao, W., Jiangfan, X., Yingchun, Z., Jianwei, W., Xiaolin, M., Yu, W., et al. (2017). Transcriptional responses of candida albicans to antimicrobial peptide MAF-1A. Front. Microbiol. 8:894. doi: 10.3389/fmicb.2017.00894

Teixeira, V., Feio, M. J., and Bastos, M. (2012). Role of lipids in the interaction of antimicrobial peptides with membranes. Prog. Lipid Res. 51, 149-177. doi: 10.1016/j.plipres.2011.12.005

Unger, T., Oren, Z., and Shai, Y. (2001). The effect of cyclization of magainin 2 and melittin analogues on structure, function, and model membrane interactions: implication to their mode of action. Biochemistry 40, 6388-6397. doi: 10.1021/ bi0026066

Wang, K., Yan, J., Dang, W., Liu, X., Chen, R., Zhang, J., et al. (2013). Membrane active antimicrobial activity and molecular dynamics study of a novel cationic antimicrobial peptide polybia-MPI, from the venom of Polybia paulista. Peptides 39, 80-88. doi: 10.1016/j.peptides.2012.11.002

Wiradharma, N., Sng, M. Y. S., Khan, M., Ong, Z. Y., and Yang, Y. Y. (2013). Rationally designed $\alpha$-helical broad-spectrum antimicrobial peptides with idealized facial amphiphilicity. Macromol. Rapid Commun. 34, 74-80. doi: 10.1002/marc.201200534

Wu, G., Ding, J., Li, H., Li, L., Zhao, R., Fan, X., et al. (2008). Effects of cations and $\mathrm{PH}$ on antimicrobial activity of thanatin and s-thanatin against Escherichia coli ATCC25922 and B. subtilis ATCC 21332. Curr. Microbiol. 57, 552-557. doi: 10.1007/s00284-008-9241-6

Wu, M., and Hancock, R. E. (1999a). Improved derivatives of bactenecin, a cyclic dodecameric antimicrobial cationic peptide. Antimicrob. Agents Chemother. 43:1274. doi: 10.1128/aac.43.5.1274

Wu, M., and Hancock, R. E. (1999b). Interaction of the cyclic antimicrobial cationic peptide bactenecin with the outer and cytoplasmic membrane. J. Biol. Chem. 274, 29-35. doi: 10.1074/jbc.274.1.29

Zhang, H., Niu, H. T., Li, G. R., and Lu, J. H. (2010). The influence of molecular structure on antimicrobial peptides' activity. Chin. J. Antibio. 35, 892-897.

Zhu, X., Dong, N., Wang, Z., Ma, Z., Zhang, L., Ma, Q., et al. (2014). Design of imperfectly amphipathic $\alpha$-helical antimicrobial peptides with enhanced cell selectivity. Acta Biomater. 10, 244-257. doi: 10.1016/j.actbio.2013.08.043

Zhu, X., Zhang, L., Wang, J., Ma, Z., Xu, W., Li, J., et al. (2015). Characterization of antimicrobial activity and mechanisms of low amphipathic peptides with different $\alpha$-helical propensity. Acta Biomater. 18, 155-167. doi: 10.1016/j.actbio. 2015.02.023

Conflict of Interest: LC and LL were employed by Beijing Sanyuan Foods Co., Ltd.

The remaining authors declare that the research was conducted in the absence of any commercial or financial relationships that could be construed as a potential conflict of interest.

Copyright (C) 2019 Sun, Gu, Hussain, Chen, Lin, Wang, Pang, Jiang, Jiang and Hou. This is an open-access article distributed under the terms of the Creative Commons Attribution License (CC BY). The use, distribution or reproduction in other forums is permitted, provided the original author(s) and the copyright owner(s) are credited and that the original publication in this journal is cited, in accordance with accepted academic practice. No use, distribution or reproduction is permitted which does not comply with these terms. 